\title{
Reproductive biology of Cipocereus minensis (Cactaceae)-A columnar cactus endemic to rupestrian fields of a Neotropical savannah
}

\author{
Cristiane Martins $^{a}$, Reisla Oliveira ${ }^{b}$, Carlos Victor Mendonça Filho $^{c}$, \\ Liliane Teixeira Lopes ${ }^{c}$, Rodrigo Assunção Silveira ${ }^{a}$, Juliana Aparecida Pereira de Silva ${ }^{a}$, \\ Ludmilla M.S. Aguiar $^{\mathrm{d}}$, Yasmine Antonini ${ }^{\mathrm{a}, \mathrm{b}, *}$
}

a Programa de Pós Graduação em Ecologia de Biomas Tropicais, Universidade Federal de Ouro Preto, MG, Brazil

${ }^{\mathrm{b}}$ Departamento de Biodiversidade e Evolução, Universidade Federal de Ouro Preto, Ouro Preto, MG, Brazil

${ }^{\mathrm{c}}$ Departamento de Biologia, Universidade Federal dos Vales do Jequitinhonha e Mucuri, Diamantina, MG, Brazil

d Departamento de Zoologia, Universidade de Brasília, Campus Universitário Darcy Ribeiro, Brasília, DF, Brazil

\section{A R T I C L E I N F O}

\section{Article history:}

Received 22 August 2015

Received in revised form

25 November 2015

Accepted 26 November 2015

Edited by Stefan Dötterl

Available online 4 December 2015

\section{Keywords:}

Cactaceae

Endemic species

Chiropterophily

Self-incompatibility

Nocturnal and diurnal pollinators

Pollen limitation

Brazil

\begin{abstract}
A B S T R A C T
We studied the reproductive biology of Cipocereus minensis, an endemic columnar cactus of the Espinhaço Mountain Range, Southeastern Brazil, focusing on floral biology, breeding system, and pollination. We described floral morphology and evaluated the role of nocturnal and diurnal pollinators on the reproductive success in two populations. $C$. minensis has large, horizontal, cream-colored, chiropterophilous flowers with rigid petals that open at dusk and close on the following morning. Flowers produced a huge amount of pollen grains and nectar production was nocturnal. Controlled pollination experiments revealed that the cactus is an obligate xenogamous species. Visitor-exclusion experiments revealed that the nocturnal visitors (bats) are the prominent pollinators whereas hummingbirds and social bees, which visited the flowers early in the morning, contributed little to fruit set. We conclude that the reproductive success of this endemic columnar cactus is threatened in the absence of the effective pollinating bats.
\end{abstract}

(c) 2015 Elsevier GmbH. All rights reserved.

\section{Introduction}

Cactaceae is a distinctive family of plants native to the Americas with approximately 1600 species. Brazil is the third global center of cacti diversity with 200 species, of which $78 \%$ are considered endemic (Taylor and Zappi, 2004; Taylor, 1997; Zappi et al., 2010). Our understanding of the reproductive biology of these plants is severely limited compared to other aspects of their biology such as morphology, physiology, biochemistry, and ethnobotany (Nobel, 2002). This is especially true in Brazil, where, the reproductive biology of less than $10 \%$ of the species has been studied (Zappi et al., 2011). These studies have included species of Pilosocereus (Locatelli et al., 1997; Rocha et al., 2007), Opuntia (Schlindwein and Wittmann, 1997), Parodia, Gymnocalycium

\footnotetext{
* Corresponding author at: Laboratory of Biodiversity, Federal University of Ouro Preto. Campus Morro do Cruzeiro, s/n-Bauxita-Ouro Preto, ZIP Code: 34500-000, MG, Brazil.

E-mail addresses: antonini.y@gmail.com, antonini@iceb.ufop.br (Y. Antonini).
}

(Schlindwein and Wittmann, 1995), Tacinga palmadora (Locatelli and Machado, 1999a), Cereus (Locatelli and Machado, 1999b; Silva and Sazima, 1995), Micranthocereus (Aona et al., 2006), Melocactus (Colaço et al., 2006; Gomes et al., 2014; Locatelli and Machado, 1999a), and Cipocereus (Rego et al., 2012).

Self-incompatibility systems in cacti are common and occur in at least 30\% of the genera (Boyle, 1997; Mandujano et al., 2010; Strong and Williamson, 2007). Studies on the pollination biology of columnar cacti have shown that most species are adapted to nectar-feeding bats (Fleming et al., 2001; Locatelli et al., 1997; Munguía-Rosas et al., 2010; Nassar et al., 1997; Rocha et al., 2007; Valiente-Banuet et al., 1997a). Among columnar cacti with batpollination systems, the relative contribution of diurnal visitors to fruit set seems to increase with increasing latitude. Thus, it is expected that in populations of extra-tropical regions, daytime visitors significantly contribute to production of seeds (Fleming et al. 2001; Munguía-Rosas et al., 2009). Some of these species are also effectively pollinated by diurnal flower visitors such as birds and bees (Fleming et al., 2001; Munguía-Rosas et al., 2009). In addition to nectar-feeding bats, some columnar cacti with nocturnal 
flowers are pollinated by hawkmoths (Clark-Tapia and MolinaFreaner, 2004; Fleming et al., 2001; Locatelli and Machado, 1999b).

All six species of the genus Cipocereus are endemic to rock outcrops of the state of Minas Gerais, Brazil. We studied the reproductive biology of C. minensis N.P. Taylor \& Zappi, a columnar cactus with nocturnal flowers, endemic to the Espinhaço Mountain Range, described floral morphology, and evaluated the reproductive system in two populations. We addressed the following questions: Is $C$. minensis pollinator-dependent for reproduction? What is the role of nocturnal and diurnal pollinators for its reproductive success?

\section{Materials and methods}

\subsection{Study area}

We studied two populations of $C$. minensis apart about $80 \mathrm{~km}$ from each other (Fig. 1) in the Espinhaço Mountain Rage, Minas Gerais. One population was located on the Diamantina Plateau $\left(18^{\circ} 11^{\prime} 48.23^{\prime \prime} \mathrm{S}, 43^{\circ} 34^{\prime} 8.74^{\prime \prime} \mathrm{W}\right)$, in an area of expansive rocky outcrops surrounding the town of Diamantina. The other was in Rio Preto State Park $\left(18^{\circ} 07^{\prime} 12.9^{\prime \prime} \mathrm{S}, 43^{\circ} 20^{\prime} 36.9^{\prime \prime} \mathrm{W}\right)$, a nature reserve located in the municipality of São Gonçalo do Rio Preto. The climate of both areas is characterized by a well-defined rainy season from November to March, and a cooler dry season from June to September. Both populations of C. minensis were located in quartzitic open grasslands at altitudes between 1020 (Diamantina) and $950 \mathrm{~m}$ a.s.l. (Rio Preto State Park). The main vegetation within the study area is 'campo rupestre' (rupestrian fields) (Pirani and Harley, 1997), forming a mosaic with riparian forests and cerrado. The studies in both areas were carried out from May 2011 to December 2012.

\subsection{Studied species}

The genus Cipocereus differs from others in the tribe Cereeae in having blue, globose, indehiscent fruits with translucent flesh (Fig. 2A). The flowers have cream-colored petals with blue sepals (Zappi et al., 2010) (Fig. 2B). The cacti occur on rocky quartzitic outcrops and their roots usually extend into the fissures of rocks or are associated with termite mounds. Two subspecies are recognized within C. minensis, subspecies leiocarpus, the taxon studied herein, and subspecies minensis. The first has larger flowers and non-ribbed smooth, and blue fruit. Those of subspecies minensis are ribbed with a few spine-bearing areoles, and are brownish, pale green, whitish, or bluish (Taylor and Zappi, 2004).

\subsection{Floral morphology and biology}

For both populations we recorded color, odor and time of anthesis of the flowers. To describe floral morphology we used 25 flowers from 15 plant individuals from the Diamantina population and eight flowers from eight plant individuals from the Rio Preto State Park. The diameter of the corolla and the length of the flower, nectar chamber, and stigma + style were measured with digital calipers.

We collected 30 flowers in pre-anthesis from 16 individuals of the Diamantina population and counted the number of stamens and pollen grains per flower. We then multiplied the mean number of pollen grains per anther by the mean number of anthers per flower (Dafni et al., 2005).

To assess the rate of nectar secretion and the sugar concentration of nectar, we bagged eight flower buds of seven individuals. We then emptied all nectar from each flower in two-hour intervals from 19:00 h to 09:00 h. The flowers were re-bagged after each measurement to exclude flower visitors. We measured nectar volume using graduated microcapillary tubes and nectar sugar concentration with a pocket refractometer (Atago ${ }^{\circledR} \mathrm{N} 1$, Brix scale $0-32 \%)$.

\subsection{Breeding system}

To determine the breeding system of $C$. minensis, we performed four treatments: (1) non-manipulated self pollination-flowers in pre-anthesis were maintained bagged without further manipulation; (2) hand self-pollination-flowers were hand-pollinated with their own pollen; (3) hand cross-pollination-flowers were emasculated and pollinated with pollen grains from at least two flowers of different individuals; and (4) natural pollination-flowers accessible to pollinators were individually marked (control).

The treatments were conducted on 126 flowers from 5 individuals of the Diamantina population and 202 flowers from 31 individuals of the Rio Preto State Park population. With the exception of the controls, flower buds were bagged with voile bags. We bagged the flowers of all treatments after senescence to protect the fruits from possible predation and determined the fruit set in each.

\subsection{Floral visitors}

In order to record flower visits by nocturnal animals, we set six camera traps (Tigrinus ${ }^{\circledR}$ and Bushnell ${ }^{\circledR}$ ), each one in front of a cactus, during three blooming seasons of $C$. minensis in Diamantina. The trapping effort was of $528 \mathrm{~h}$ (April 2011), $4320 \mathrm{~h}$ (August to October 2011) and $3600 \mathrm{~h}$ (January to February 2012). Diurnal floral visitors were recorded ad libitum, (no systematic method; Altman, 1974) and through photographic records for Diamantina, throughout the study period.

\subsection{Visitor-exclusion experiments}

To evaluate the effectiveness of diurnal and nocturnal pollinators, we conducted exclusion experiments during four consecutive days/nights for Rio Preto and six days/nights for Diamantina. In order to exclude diurnal visitors, flowers were bagged at around $5: 30 \mathrm{~h}$ in the morning until the end of anthesis ( 5 individuals and 33 flowers - Diamantina; 20 individuals and 51 flowers - Rio Preto). To exclude nocturnal visitors, flowers were bagged from 17:30 h to $5: 30 \mathrm{~h}$ the next morning (5 individuals and 33 flowers - Diamantina; 20 individuals and 56 flowers - Rio Preto).

\subsection{Statistical analysis}

Generalized linear models (GLM) using quasi-poison error distribution with log link function (after residual analyses) were constructed to compare fruit sets in the visitor-exclusion experiments and among the pollination treatments used to determine the breeding system of the plant. The the response variable was fruit set and the explanatory variables were treatment and plant individual (used as a random factor). Contrast analyses were performed after the construction of the models. A multivariate analysis of variance (MANOVA) was performed to assess differences in flower morphology between the two populations. Analyses were performed in Statistica 8.0 (MANOVA) and R (GLM).

\section{Results}

\subsection{Floral morphology and biology}

C. minensis showed large, robust, cream colored flowers, with a large number of stamens $(303 \pm 42)$ and pollen grains $(417.865 \pm 3.345)$. They have a wide nectar chamber, which is approximately one third of the total length of the flower. Flower 


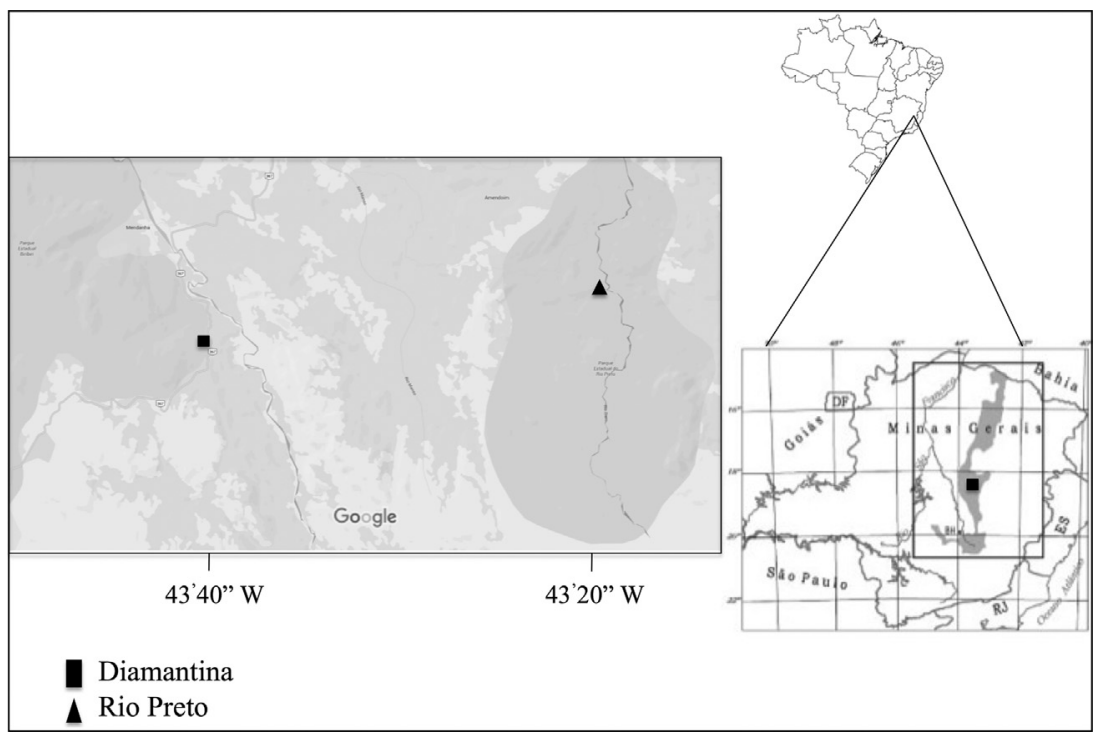

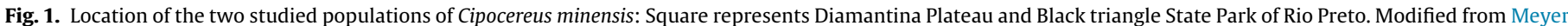
and Franceschinelli (2011).

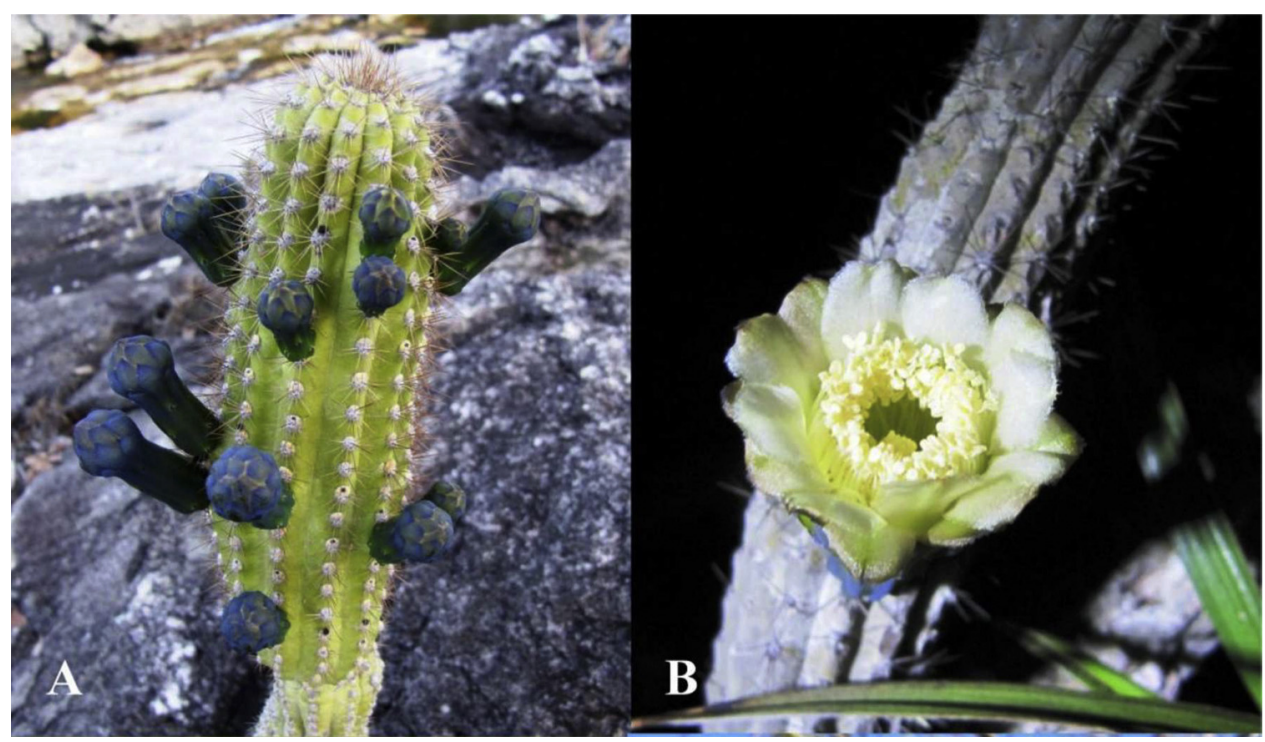

Fig. 2. Cipocereus minensis. (A) Flower buds and (B) flower.

Table 1

Floral morphology of Cipocereus minensis (mean \pm SD).

\begin{tabular}{|c|c|c|c|c|}
\hline Size $(\mathrm{cm})$ & Diamantina $(n=15)$ & Range & Rio Preto $(n=8)$ & Range \\
\hline Diameter of the corolla & $3.28 \pm 0.37^{a}$ & $2.69-3.97$ & $3.06 \pm 0.26^{\mathrm{a}}$ & $2.69-3.74$ \\
\hline Flower length & $4.61 \pm 0.66^{\mathrm{a}}$ & $3.54-6.34$ & $4.90 \pm 0.44^{\mathrm{a}}$ & $4.46-5.47$ \\
\hline Length of the nectar chamber & $1.30 \pm 0.22^{\mathrm{a}}$ & $0.91-1.89$ & $1.16 \pm 0.09^{\mathrm{b}}$ & $1.04-1.26$ \\
\hline Length of stigma + style & $2.74 \pm 0.47^{\mathrm{a}}$ & $2.34-3.33$ & $3.31 \pm 0.34^{\mathrm{b}}$ & $2.73-3.68$ \\
\hline
\end{tabular}

Statistical differences are represented by different letters.

Table 2

Fruit set after different treatments of flowers of Cipocereus minensis of the Serra do Espinhaço, Minas Gerais, Brazil.

\begin{tabular}{|c|c|c|c|c|c|c|c|c|}
\hline \multirow[b]{2}{*}{ Treatment } & \multirow[b]{2}{*}{ Plants } & \multicolumn{3}{|c|}{ Diamantina } & \multirow[b]{2}{*}{ Plants } & \multicolumn{3}{|l|}{ Rio Preto } \\
\hline & & Flowers & Fruits & $\%$ & & Flowers & Fruits & $\%$ \\
\hline Spontaneous self pollination & 5 & 33 & 0 & - & 19 & 84 & 0 & - \\
\hline Manual self pollination & 5 & 20 & 0 & - & 12 & 28 & 0 & -- \\
\hline Manual cross pollination & 5 & 23 & 19 & 83 & 7 & 16 & 16 & 100 \\
\hline Natural pollination (control) & 5 & 50 & 40 & 80 & 21 & 74 & 46 & 62 \\
\hline Night pollination & 5 & 33 & 11 & 33 & 14 & 51 & 27 & 53 \\
\hline Day pollination & 5 & 33 & 4 & 12 & 15 & 56 & 9 & 16 \\
\hline
\end{tabular}




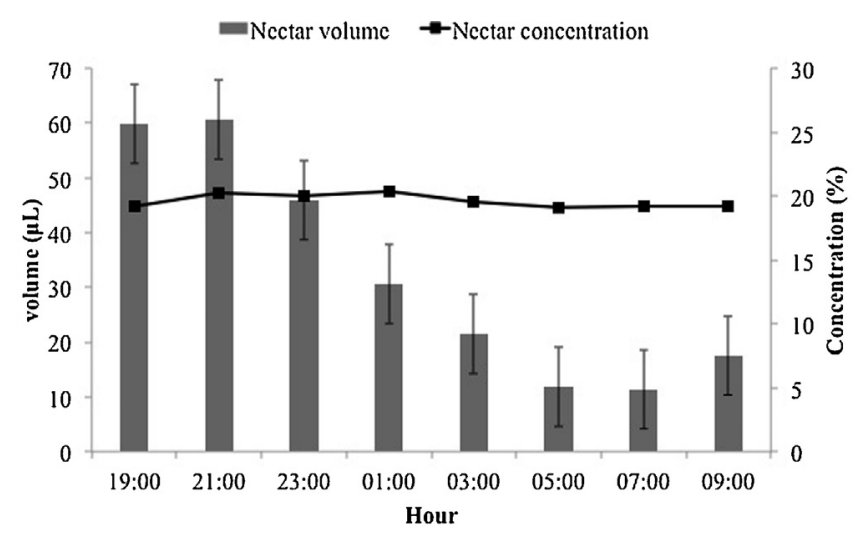

Fig. 3. Average production and concentration (given as production per two hours) of nectar from Cipocereus minensis (eight flowers from seven individuals) throughout the anthesis. Whiskers indicate mean \pm standard error.

morphology only differs between populations by the nectar cham$\operatorname{ber}\left(F_{3,22}=-3.67, p<0.001\right)$ and stigma + style length $\left(F_{3,22}=-3.05\right.$, $p<0.01$ ) (Table 1 ).

At the beginning of anthesis, at dusk, the flowers already emitted a mild sweet odor. In the Diamantina population, flowers started opening from $17: 30 \mathrm{~h}$ to $18: 30 \mathrm{~h}$ and were fully open between 19:00 $\mathrm{h}$ and 21:00 h. In the Rio Preto population, the beginning of anthesis was one to two hours delayed. The flowers remained open until late morning and closed definitively around 11:00 h in both populations.

The mean total production of nectar per flower was $260 \mu \mathrm{L}$ and the mean sugar concentration $20 \pm 0.5 \%(n=8)$. Nectar production per flower was high in the first hours of anthesis, between 19:00 $\mathrm{h}$ and $21: 00 \mathrm{~h}(60 \mu \mathrm{L} / 2 \mathrm{~h})$, and diminished continuously until dawn $(10 \mu \mathrm{L} / 2 \mathrm{~h})$. Sugar concentration of nectar remained stable throughout anthesis (Fig. 3 ).

\subsection{Breeding system}

C. minensis was self-incompatible and fruit set occurred only after hand cross-pollination and natural pollination (control) at a rate of $83 \%$ and $80 \%$, respectively, for the Diamantina population and $100 \%$ and $62.2 \%$, respectively, for the Rio Preto population (Table 2). Fruit set was different among the treatments both in Diamantina $\left(F_{3,17}=22.97, p<0.001\right)$ and Rio Preto $\left(F_{3,51}=5.218\right.$, $p<0.004)$. Fruit set between individuals was not different, both in Rio Preto $\left(F_{25}=0.794, p=0.710\right)$ and Diamantina $\left(F_{4}=0.932\right.$, $p=0.230)$. Hand cross-pollination and natural pollination did not differ in the Diamantina population $\left(F_{1,9}=0.234, p>0.05\right)$, whereas in the Rio Preto population hand cross-pollinated flowers set significantly more fruits than those accessible to pollinators (control) $\left(F_{1,24}=13.909, p<0,005\right)$ (Table 2$)$.

\subsection{Visitor-exclusion experiment}

Flowers available exclusively to nocturnal visitors set significantly more fruits than those available exclusively to diurnal visitors in both populations (Diamantina $-F_{1,8}=5.69, p=0.04 /$ Rio Preto $-F_{1,27}=9.64, p<0.001$ ). Fruit set by nocturnal visitors was $33 \%$ and 53\% in Diamantina and Rio Preto populations, respectively. Fruit set in flowers exclusively accessible to diurnal visitors was only $12 \%$ and $16.7 \%$, respectively (Table 2 ).

\subsection{Floral visitors}

In the Diamantina population, ten nocturnal visits by bats of Anoura sp.(Phyllostomidae) and six diurnal visits by hummingbirds of Phaethornis pretrei and Eupetomena macroura (Trochilidae) were recorded in the $C$. minensis flowers using camera traps. Worker bees of Apis mellifera and Trigona sp. (Apidae), as well as small beetles (Nitidulidae) were observed visiting flowers early in the morning.

\section{Discussion}

Our study shows that the endemic columnar cactus $C$. minensis is a self-incompatible species, pollinated almost exclusively by nocturnal flower visitors in both studied populations. The diurnal generalist visitors, highly social honeybees and stingless bees, and nectar seeking hummingbirds, provided only a minor contribution to fruit set. Floral traits such as large, robust and fleshy creamcolored flowers without nectar guides, a short flower tube with numerous stamens with a huge amount of pollen, and the high rates of nectar production during the night decreasing until dawn, are all typical adaptations to bat pollination (chiropterophily) (Faegri and Van Der Pijl, 1979; Vogel, 1968).

The extended period of anthesis and the continuous, but low, nectar secretion during the following morning, also permits visits to the flowers by generalist eusocial bees looking for pollen, and sporadic visits by hummingbirds which take-up the remaining nectar. However, considering the results of the exclusion experiment, bats, but not bees and hummingbirds, are the best pollinators of $C$. minensis, in spite of their low frequency of flower visits. Furthermore, floral biology and morphology as well as nocturnal anthesis are consistent with chiropterophily, reinforcing the statement that only part of the pollinator species or functional groups of them (bats in our case) exert strong selective pressures on floral traits (Fenster et al., 2004; Reynolds et al., 2009).

For some columnar cacti, a nocturnal floral cycle that extends into the following day has been suggested to be a strategy to ensure sexual reproduction when there is spatial and temporal variation in the frequency of nocturnal pollinators (Fleming et al., 2001). Pollination studies with columnar cacti in Mexico suggest that specialized pollination systems like that of chiropterophily prevail in tropical regions, whereas in extra-tropical regions, insects and hummingbirds would frequently be complementary pollinators in bat pollinated species (Fleming et al., 2001; Valiente-Banuet et al., 1996, 1997a,b).

In only six of the approximately 100 species of Cereeae columnar cacti (sensu Zappi et al., 2010) has the pollination system been studied in detail [Cereus horrispinus Backeb, Cereus repandus Mill. (Nassar et al., 1997) Pilosocereus chrysacanthus (Weber) Byles \& Rowley (Valiente-Banuet et al., 1997b), Pilosocereus lanuginosus (L.) Byles \& Rowley (Nassar et al., 1997), Pilosocereus royenii (L.) Byles \& Rowley (Rivera-Marchand and Ackerman, 2006) and Pilosocereus tuberculatus (Werdermann) Byles \& Rowley (Rocha et al., 2007)]. All of them are tropical and exhibit a bat-specialized pollination system, even if diurnal visitors account for a minor contribution to fruit set. However, information on reproductive biology of the Southern hemisphere cacti is scarce, preventing conclusions about the occurrence of this pattern for this region (Munguía-Rosas et al., 2009).

Fruit set exclusively from cross-pollination is widespread in cacti species (see review Mandujano et al., 2010). Fruit set exclusively from cross-pollination in C. minensis as well as demonstrated for co-generic species (Cipocereus laniflorus-Rego et al., 2011, Cipocereus crassissepalus-Martins et al. unpublished) and other representatives of Cereeae (Clark-Tapia and Molina-Freaner, 2004; Ibarra-Cerdeña et al., 2005; Strong and Williamson, 2007; ValienteBanuet et al., 1997).

Our results indicate the occurrence of pollinator limitation on fruit set in the Rio Preto population but not in Diamantina, whereas the Diamantina but not the Rio Preto population seems to be 
resource limited. Low visitation frequency, variation in pollination efficiency, and pollinators sharing has been identified as possible causes of pollinator limitation (Ashman et al., 2004; Hegland and Totland, 2007; Pinto and Schlindwein, 2015). In the Rio Preto Park (and not in Diamantina), C. minensis occurs with further two columnar cacti, Pilosocereus aurisetus (Werderm.) Byles \& G.D. Rowley and Cipocereus crassisepalus (Buining and Brederoo) Zappi \& N.P. Taylor. Both species are chiropterophilous and their blooming periods overlap largely (P. aurisetus) or partially (C. crassissepalus) with that of $C$. minensis (Martins et al., pers. obs.).

Populations of $C$. minensis occur in rocky habitats, from c. $750 \mathrm{~m}$ to $1500 \mathrm{~m}$ of altitude (Taylor and Zappi, 2004), which is a constrained habitat with a huge thermic amplitude, low water and resource availability, and sporadic fire (Taylor and Zappi, 2004). Although both populations occur in such a habitat, the fruit set in manual cross pollination treatments was only less than $100 \%$ in Diamantina indicating that in this but not in the Rio Preto population there are insufficient resources to produce fruits. Furthermore, inbreeding depression might constrain fruit set in the small-sized population of Diamantina.

The flowers of the two studied populations of $C$. minensis differ only in the size of the nectar chamber and in the stigma length. Because both populations depend on bat pollination, such differences do not result in a shift from nocturnal to diurnal pollinators. An important implication for conservation of endemic and endangered species, such as $C$. minensis, is the loss of main pollinators. The entire Cactaceae family is listed as endangered in the Convention on International Trade in Endangered Species (CITES). For columnar cacti, studies on possible population decreases of the bat pollinators and their viability are required to better understand the cacti's reproductive constraints.

\section{Acknowledgements}

We are grateful to the following for providing scholarships: Conselho Nacional de Pesquisa (CNPq) to Y. A., Coordenação de Aperfeiçoamento de Pessoal de Nível Superior (CAPES) to C.M. and R.O., Universidade Federal de Ouro Preto (UFOP) to J.P., and Fundação de Amparo à Pesquisa do Estado de Minas Gerais (FAPEMIG) to L.L. We thank the Instituto Estadual de Florestas (IEF) for permission to work in the nature reserve and the director of the reserve, Antônio Almeida Tonhão, for logistic support. CAPES supported the study. Clemens Schlindwein for helpful suggestions and Erik Wild for English revision.

\section{References}

Altman, J., 1974. Observational study of behavior: sampling methods. Behaviour 3, 227-267.

Aona, L.Y.S., Machado, M., Panarin, E.R., Castro, C.C., Zappi, D., Amaral, M.C.E., 2006. Pollination biology of three Brazilian species of Micranthocereus Backeb. (Cereeae, Cactoideae) endemic to the campos rupestres. Bradleya 24, 39-52.

Ashman, T.L., Knight, T.M., Steets, J.A., Amarasekare, P., Burd, M., Campbell, D.R., Dudash, M.R., Johnston, M.O., Mazer, S.J., Mitchell, R.J., Morgan, M.T., Wilson, W.G., 2004. Pollen limitation of plant reproduction: ecological and evolutionary causes and consequences. Ecology 85, 2408-2421.

Boyle, T.H., 1997. The genetics of self-incompatibility in the genus Schlumbergera (Cactaceae). J. Hered. 88, 209-214.

Clark-Tapia, R., Molina-Freaner, F., 2004. Reproductive ecology of the rare clonal cactus, Stenocereus eruca, in the Sonoran Desert. Plant Syst. Evol. 247, 155-164.

Colaço, M.A., Fonseca, R., Lambert, S.M., Costa, C.B., Machado, C.G., Borba, E.L. 2006. Reproductive biology of Melocactus glaucescens Buining \& Brederoo and $M$. paucispinus G. Heimen \& R. Paul (Cactaceae) in the Chapada Diamantina, northeastern Brazil. Braz. J. Bot. 29, 239-249.

Dafni, A., Kevan, P.G., Husbande, B.C., 2005. Practical Pollination Biology. Ontário, Canada.

Faegri, K., Van Der Pijl, L., 1979. Principles of Pollination Ecology. Pergamon Press Oxford, UK.

Fenster, C.B., Armbruster, W.S., Wilson, P., Dudash, M.R., Thomson, J.D., 2004. Pollination syndromes and floral specialization. Ann. Rev. Ecol. Syst. 35, 375-403.
Fleming, T.H., Shaley, C.T., Holland, J.N., Nason, J.D., Hamrick, J.L., 2001. Sonoran desert columnar cacti and the evolution of generalized pollination systems. Ecol. Monograph. 71, 511-530.

Gomes, V.G.N., Quirino, Z.G.M., Machado, I.C., 2014. Pollination and seed dispersal of Melocactus ernestii Vaupel subsp. ernestii (Cactaceae) by lizards: an example of double mutualism. Plant Biol. 16, 315-322.

Hegland, S.J., Totland, O., 2007. Pollen limitation affects progeny vigour and subsequent recruitment in the insect-pollinated herb Ranunculus acris. Oikos 116, 1204-1210.

Ibarra-Cerdeña, C.N., Iñiguez-Dávalos, L.I., Sánchez-Cordero, V., 2005. Pollination ecology of Stenocereus queretaroensis (Cactaceae), a chiropterophilous columanr cactus, in a tropical dry forest of Mexico. Am. J. Ecol. 92, 503-509.

Locatelli, E., Machado, I.C.S., Medeiros, P., 1997. Floral biology and pollination in Pilosocereus catingicola (Cactaceae) in Northeastern Brazil. Bradleya 15, 28-34.

Locatelli, E., Machado, I.C.S., 1999a. Comparative study of the floral biology in two ornithophilous species of Cactaceae: Melocactus zehntneri and Opuntia palmadora. Bradleya 17, 75-85.

Locatelli, E., Machado, I.C.S., 1999b. Floral biology of Cereus fernambucensis: a sphingophilous cactus of restinga. Bradleya 17, 86-94.

Meyer, S.T., Franceschinelli, E.V., 2011. Influência de variáveis limnológicas sobre a comunidade das macrófitas aquáticas em rios e lagoas da Cadeia do Espinhaço, 62. Rodriguésia, Minas Gerais, Brasil, pp. 743-758.

Mandujano, M.C., Carrillo-Angeles, I.G., Martínez-Peralta, C., Golubov, J., 2010. Reproductive biology of Cactaceae. In: Ramawat, K.G. (Ed.), Desert Plants-Biology and Biotechnology. Springer Berlin, Heidelberg, DE, pp. 30-197.

Munguía-Rosas, M.A., Sosa, V.J., Ojeda, M.M., De-Nova, J.A., 2009. Specialization clines in the pollination systems of agaves (Agavaceae) and columnar cacti (Cact aceae): a phylogenetically-controlled meta-analysis. Am. J. Bot. 96, 1887-1895.

Munguía-Rosas, M.A., Sosa, V.J., Jácome-Flores, M.E., 2010. Pollination system of the Pilosocereus leucocephalus columnar cactus (tribe Cereeae) in eastern Mexico. Plant Biol. 12, 578-586.

Nassar, J.M., Ramírez, N., Linares, O., 1997. Comparative pollination biology of Venezuelan columnar cacti and the role of nectar-feeding bats in their sexual reproduction. Am. J. Bot. 84, 918-927.

Nobel, P.S., 2002. Cacti: Biology and Uses. University of California, Berkeley, California, USA.

Pinto, C.E., Schlindwein, C., 2015. Pollinator sharing and low pollen-ovule ratio diminish reproductive success in two sympatric species of Portulaca (Portulacaceae). Stud. Neotrop. Fauna Environ. 50, 4-13.

Pirani, J.R., Harley, R.M., 1997. Espinhaço range region, Eastern Brazil. In: Davis S.D., Heywood, V.H., Herrera-Macbryde, O., Villa-Lobos, J., Hamilton, A.C. (Eds.), Centres of Plant Diversity. A Guide and Strategy for their Conservation. The Americas. IUCN Publication Unity, Cambridge, pp. 397-404.

Rego, J.O., Franceschinelli, E.V., Zappi, D.C., 2012. Reproductive biology of a highly endemic species: Cipocereus laniflorus N.P. Taylor \& Zappi (Cactaceae). Acta Bot. Bras. 26, 243-250.

Reynolds, R.J., Westbrook, M.J., Rhode, A.S., Cridland, J.M., Fenster, C.B., Dudash, M.R., 2009. Pollinator specialization and pollination syndromes of three related North American Silene. Ecology 90, 2077-2087.

Rivera-Marchand, B., Ackerman, J.D., 2006. Bat pollination breakdown in the Caribbean columnar cactus Pilosocereus royenii. Biotropica 38, 635-642.

Rocha, E.A., Machado, I.C., Zappi, D.C., 2007. Floral biology of Pilosocereus tuberculatus (Werderm.) Byles \& Rowley: a bat pollinated cactus endemic from the "Caatinga" in northeastern Brazil. Bradleya 25, 129-144.

Schlindwein, C., Wittmann, D., 1995. Specialized solitary bees as effective pollinators of South Brazilian species of Notocactus and Gymnocalycium. Bradleya 13, 25-34.

Schlindwein, C., Wittmann, D., 1997. Stamen movements in flowers of Opuntia (Cactaceae) favour oligolectic bee pollinators. Plant Syst. Evol. 204, 179-193.

Silva, W.R., Sazima, M., 1995. Hawkmoth pollination in Cereus peruvianus, a columnar cactus from southeastern Brazil. Flora 190, 339-343.

Strong, A.W., Williamson, P.S., 2007. Breeding system of Astrophytum asterias: an endangered cactus. Southwest Nat. 52, 341-346.

Taylor, N., 1997. Cactaceae. In: Oldfield, S. (Ed.), Cactus and Succulent Plants-Status Survey and Conservation Action Plan. IUCN/SSC Cactus and Succulent Specialist Group. IUCN, Gland, Switzerland and Cambridge, UK, pp. $17-20$.

Taylor, N.P., Zappi, D.C., 2004. Cacti of Eastern Brazil. Kew: Royal Botanic Gardens, UK.

Valiente-Banuet, A., Arizmendi, M.D.C., Rojas-Martínez, A., Domínguez-Canseco, L., 1996. Ecological relationships between columnar cacti and nectar-feeding bats in Mexico. J. Trop. Ecol. 12, 103-119.

Valiente-Banuet, A., Rojas-Martinez, A., Arizmendi, M.D.C., Davila, P., 1997a. Pollination biology of two columnar cacti (Neobuxbaumia mezcalaensis and Neobuxbaumia macrocephala) in the Tehuacan Valley, central Mexico. Am. J. Bot. $84,452$.

Valiente-Banuet, A., Rojas-Martıínez, A., Casas, A., del Coro Arizmendi, M., Dávila, P., 1997b. Pollination biology of two winter-blooming giant columnar cacti in the Tehuacán Valley, central Mexico. J. Arid Environ. 37, 331-341.

Vogel, S., 1968. Chiropterophilie in der neotropischen, Neue Mitteilungen. Flora $157,562-602$

Zappi, D.C., Taylor, N.P., Machado, M.C., 2010. Cactaceae. In: Forzza, R.C. Baumgratz, F.A., Bicudo, C.E.M., Canhos, D.A.L., Carvalho Jr., A.A., Costa, A., 
Costa, D.P., Hopkins, M., Leitman, P.M. Lohmann, L.G., Nic Lughadha, E., Maia, L.C., Martinelli, G., Menezes, M., Morim, M.P., Nadruz Coelho, M.A., Peixoto, A.L., Pirani, J.R., Prado, J., Queiroz, L.P., Souza, S., Souza, V.C., Stehmann, J.R.,

Sylvestre, L.S., Walter, B.M.T., Zappi, D.C. (Eds.), Catálogo de Plantas e Fungos do Brasil, 1. Jardim Botânico do Rio de Janeiro, Rio de Janeiro, Brasil, pp. 822-832.
Zappi, D., Ribeiro-Silva, S., Aona, L.Y.S., Taylor, N., 2011. Aspectos ecológicos e biologia reprodutiva. In: Ribeiro-Silva, S., Zappi, D., Taylor, N., Machado, M. (Eds.), Plano de Ação Nacional Para a Conservação das cactáceas. Instituto Chico Mendes de Conservação da Biodiversidade, ICMBIO, Brasília, Brasil, pp. 38-43. 